\title{
Induced Abortion Cannot Become a Human Right
}

\section{Giuseppe Benagiano ${ }^{* *}$ and Claudio Sartea ${ }^{2}$}

${ }^{1}$ Department of Gynaecology, Obstetrics and Urology, "Sapienza” University of Rome, Rome, Italy

${ }^{2}$ Department of Law, University of Rome "Tor Vergata", Rome, Italy

\begin{abstract}
A careful analysis of existing documents, whether international of national, leads to the conclusion that there is no convincing evidence of the existence of an "unrestricted right to abortion". Indeed, even when access to abortion has been declared a constitutionally protected right, this access can be subject to qualification.

In addition, we believe that it is not possible to establish a right to abortion, both because of the structure of individual rights and because of the specific nature of the request for an abortion. This means that discussing the existence of a "right to abortion" has become a political and social issue, not a theoretical one. It is a question that cannot be resolved, once and for ever, in a non ideological fashion since it presents an irresolvable dilemma between the universal and abstract right to life of all human beings, and the reality of an actual power by the parents (and the mother in particular) to deny such a right to the product of conception.

For this reason, we believe that the duty of international and national institutions is not so much to linger on sterile and contradictory discussions of the nature and extent of a hypothetical right to terminate a pregnancy, but to identify remedies and develop constructive strategies to promote a conscious and responsible procreation that should include adequate protection for new human life.
\end{abstract}

\section{Introduction}

During the second half of the XX century, the possibility of obtaining the ancient practice of Induced Abortion (IA) has been made legal in various forms in most countries of the globe.

Recently the idea that access to unrestricted abortion constitutes a human right of every woman has been aired within the International Community. For this reason, we have decided to review this topic to show how - to this day - a "Right to Abortion" (RA) has not been enshrined in any binding international document, be it a universal convention, declaration, agreement or treaty.

We are fully aware that in public debates and occasionally even in discussing a legal doctrine, or in the ruling of a national court, the expression "right to interrupt a gestation" has been used. In particular this has happened in the context of controversial argumentations aimed at legitimising ruling on "procreative damages" and even on a hypothetical "right not to be born if severely handicapped". This, however, does not modify our contention that - to this day - no RA has been introduced in a legally-binding international instrument.

Based on this situation, we wish to submit a series of theoretical and juridical considerations to try and explain why there cannot be a "right to abortion", in spite of repeated requests at the national and international level and of ideological and political pressure.

Finally, we will attempt an analysis of anthropologic issues pertaining to IA capable of conditioning its acceptance even at a juridical level.

\section{Unrestricted Access to Induced Abortion is not a de jure condito "right"}

\section{Global international agreements}

A number of initiatives are being promoted at a cultural, as well as political level to have unrestricted access to IA recognised as a "human right". For instance the Center for Reproductive Rights [1] keeps an updated map of national abortion legislations where it is stated "a woman's right to safe and legal abortion is supported by numerous binding international treaties, grounded in the rights to life; health; liberty and security of person; privacy; equality and nondiscrimination; information; freedom from torture or cruel, inhuman or degrading treatment or punishment; and the enjoyment of the benefits of scientific progress". The Website however, fails to name even one national or international binding document where the concept of "abortion as a human right" is detailed. On the contrary, on the basis of a careful analysis of binging international instruments, on 25 March 2011, a Group of jurists, intellectuals, physicians and researchers have carefully reviewed the subject and produced a statement, the San José Articles, that clearly affirms: "There exists no rights to abortion under international law, either by ways of treaty obligation or under customary international law. No United Nations treaty can accurately be cited as establishing or recognizing a right to abortion" (Art. 5) [2].

Indeed, up to the present time, there is no treaty affirming that induced abortion should be considered a recognised human right. Starting with the most relevant documents, the Universal Declaration of Human Rights of 1948 [3], if anything, contains statements that go in the opposite direction: the unrestricted right to life (Art. 3); the right to recognition everywhere as a person before the law (Art. 6); the prohibition against any discriminatory practice (Art. 7); family rights (Art. 16); motherhood's special protection (Art. 25); and the duties to the community (Art. 29). Along similar lines, the Universal Declaration of the Rights of the Child of 1959 [4] in Principle 4 specifically mentions the duty to ensure that children and their mothers have access to "adequate pre-natal and post-natal care". In addition, in the

${ }^{*}$ Corresponding author: Giuseppe Benagiano, Department of Gynaecology, Obstetrics and Urology, "Sapienza" University of Rome, Rome, Italy, E-mail: gbenagiano@libero.it

Received May 31, 2013; Accepted July 26, 2013; Published July 29, 2013

Citation: Benagiano G, Sartea C (2013) Induced Abortion Cannot Become a Human Right. J Clin Res Bioeth 4: 152. doi:10.4172/2155-9627.1000152

Copyright: ( 2013 Benagiano G, et al. This is an open-access article distributed under the terms of the Creative Commons Attribution License, which permits unrestricted use, distribution, and reproduction in any medium, provided the original author and source are credited. 
final Principle 10, any form of discrimination is banned.

The 1979 United Nations Convention on the Elimination of All Forms of Discrimination against Women (CEDAW) [5], specifies that "adoption by States Parties of special measures, including those measures contained in the present Convention, aimed at protecting maternity shall not be considered discriminatory"(Art. 4), and that the interest of children represents "primordial consideration in all cases" (Art. 5). Therefore, the protection granted to pregnant women, means recognition of the value of matrimony and motherhood, even within the framework of family planning, as specified in Art. 12 and 16.

More recently two major Conferences have further advanced specific rights of women: the International Conference on Population and Development (ICPD), held in Cairo in September 1994 [6] and the Fourth World Conference on Women, held in Beijing in September 1995 [7]. The definition of the new concept of Reproductive Health and the recognition of Reproductive Rights were among the most important achievements of these Conferences. It has to be emphasised that, at the end of a heated debate, the proposed definition of Reproductive Health that contained a reference to a right to "access to safe, effective, affordable and acceptable methods of fertility regulation" (that includes abortion) was modified. The approved definition states "Reproductive health therefore implies that people are able to have a satisfying and safe sex life and that they have the capability to reproduce and the freedom to decide if, when and how often to do so. Implicit in this last condition are the right of men and women to be informed and to have access to safe, effective, affordable and acceptable methods of family planning of their choice, as well as other methods of their choice for regulation of fertility which are not against the law, and the right of access to appropriate health-care services that will enable women to go safely through pregnancy and childbirth and provide couples with the best chance of having a healthy infant." To make things even clearer, the Conference resolved that abortion should not be considered a method of family planning. To stress the non-existence of a RA, prior to the Conference Al Gore, then the Vice-President of the United States stated: "Let us get a false issue off the table: the US does not seek to establish a new international right to abortion, and we do not believe that abortion should be encouraged as a method of family planning." [8]. This position was reconfirmed by the United States Ambassador to the UN in 2005 with the words: "Nongovernmental organizations are attempting to assert that Beijing in some way creates or contributes to the creation of an internationally recognized fundamental right to abortion"... "There is no fundamental right to abortion. And yet it keeps coming up largely driven by NGOs trying to hijack the term and trying to make it into a definition" [9].

\section{European Union Agreements}

Coming now to the European Union, its fundamental Document (the Charter of fundamental rights of the European Union) [10], makes no mention of a "right to abortion". On the contrary, in the Treaty of Lisbon [11] in its first three Articles, there is a clear reference to the protection of human dignity and to the right to life and individual integrity. In addition, Art. 23 support non-discriminatory practices and Art. 24 and 26, mention the rights of the child and of people with disabilities.

The European Convention on Human Rights of 1950 [12], created a European Court to safeguard the correct application of the Convention's principles, the first being (Art. 2) the right to life.

\section{National Instruments}

Over the last decades national legislations have almost universally legalised induced abortion in various forms [1]; at the same time a careful reading does not permit to conclude that in most, if not all cases they have attributed or recognised IA as a "human right".

Besides legislative bodies of Scandinavian Countries who were the first to legalise IA, an early authoritative voice defining pregnancy termination as a woman's free choice (and therefore, indirectly, her right) was the United States Supreme Court with its ruling in the Roe vs. Wade case of 1973 [13]. While space limitation does not permit to detail the enormous and still ongoing debate this decision created within the United States, it is important to stress that the Court did not create an unlimited right. On the one hand, women in the US have today the right to request a legal IA; on the other, each State maintains its right to adopt regulations governing conditions under which the constitutional right to privacy can be exercised. In addition, mention must be made of the opinion of some of the most respected Constitutional scholars, who, on the one hand, declared themselves "Pro-choice", and, on the other, refuted the concept that a woman's free choice could be based on a right granted by the Constitution. Three examples will illustrate this point: Laurence Tribe (Professor of constitutional law at Harvard University), noted, right after the decision, that "one of the most curious things about Roe is that, behind its own verbal smokescreen, the substantive judgment on which it rests is nowhere to be found" [14]. Edward Lazarus, a former member of the staff of Judge Blackman, who wrote the Court's opinion, stated that "Roe must be ranked among the most damaging of judicial decisions"... "What, exactly, is the problem with Roe? The problem, I believe, is that it has little connection to the Constitutional right it purportedly interpreted. A constitutional right to privacy broad enough to include abortion has no meaningful foundation in constitutional text, history, or precedent - at least, it does not if those sources are fairly described and reasonably faithfully followed" [15]. Finally, John Hart Ely (Professor of constitutional law at Yale, Harvard and Stanford Universities), observed: "What is frightening about Roe is that this super-protected right is not inferable from the language of the Constitution, the framers' thinking respecting the specific problem in issue, any general value derivable from the provisions they included, or the nation's governmental structure" [16].

We believe that the motivation at the base of the U.S. Supreme Court decision, namely the "right to privacy, best expression of personal freedom", cannot be extended to managing a pregnancy, at least based on most European Constitutions. In Europe a number of constitutional texts contain language formally opposed to the existence of a "right to abortion".

Indeed, European national legislations, while in some cases permitting unrestricted access to IA, have shied away from defining abortion as a "human right", let alone a "fundamental one". This is why it seems contradictory that the Council of Europe passed a resolution that, on one hand declared that "Abortion must, as far as possible, be avoided. All possible means compatible with women's rights must be used to reduce the number of both unwanted pregnancies and abortions", and, on the other declared that "in member states where abortion is permitted for a number of reasons, conditions are not always such as to guarantee women effective access to this right" [17].

It is impossible to review here every national law concerning IA. Therefore we will limit our analysis to three important legislative European instruments: those of Germany, Spain and Italy.

In 1993, the German Constitutional Court (decision BVerfGE 39,1 ) established that the Constitution guaranties the "unborn" a right 
to life and abortion is "an act that kills"[18]. In addition, after German re-unification the Court declared unconstitutional the abortion law existing in the former DDR (German Democratic Republic) [19].

In 2010, Spain adopted a new Law on IA liberalising access and motivations. The preamble clearly states: "The present law recognises the right to a freely decided motherhood, implying, among others, that women can take the initial decision over their pregnancy and that this decision, conscientious and free is to be respected" (La presente Ley reconoce el derecho a la maternidad libremente decidida, que implica, entre otras cosas, que las mujeres puedan tomar la decisión inicial sobre su embarazo y que esa decisión, consciente y responsable, sea respetada) [20]. This text, while affirming the "right to freely accepted motherhood", as well as the need to protect pre-natal life, does not mention a "right to abortion".

In Italy, Article 1 of the legislation legalising IA (Law 194/1978) [21] affirms the duty of the State to "protect human life from its inception and the 'social value of motherhood". The Italian constitutional jurisprudence on these themes has never affirmed the existence of a "right to abortion", balancing in the best possible way the right to life of the unborn and the right to health of the mother, rejecting the concept of an "equivalence between the right to life and health of the mother who is already a person and the embryo who is not yet a person" [22].

\section{Abortion cannot be Considered a Human Right}

\section{Theoretical considerations}

In defining a right, clarity is the first parameter; for this reason, it is important to go back to the accepted definition of "human rights", as it appears, for example, in the United Nations website [23]. There, the meaning of the two words is explained as follows: "human" means " $a$ member of the Homo sapiens species; a man, woman or child; a person", and "rights" are the "things to which you are entitled or allowed; freedoms that are guaranteed". As a consequence, "human rights" are "the rights you have simply because you are human".

In Europe, but not only there, during the XIX century the development of an overall doctrine of rights led to the definition of a key notion, that of "individual rights" that conceptually and historically precedes that of "human rights". They represent a special category, having to do with essential things and, as such, are proclaimed and protected universally, even against a country' own legislation $[24,25]$.

Recognition of individual rights has come at the end of a long historical elaboration process through which individuals, with their rights and obligations have been placed at the centre of juridical discourses. Two types of rights have been acknowledged through this process: those emerging from private obligations and the fundamental ones to be recognised in modern Constitutions as civil, political and social rights. The latter have to be recognised in legislative instruments as capable of satisfying primary exigencies of individuals, whether material (food, health, physical integrity, etc.), or immaterial (culture, education, religion, work, etc.). Any modern state is bound to recognise these needs as essential and therefore worth of full protection.

If we apply this simple scheme to the proposed "right to abortion", it becomes immediately clear how incongruous it is to include it in the category of a right satisfying a primary need of an individual, without infringing on someone else's rights.

First, a RA is - by its very nature - to be coupled by a "non-right to life" of the product of conception; or by the contention that the product of conception should not be considered a juridical person. In this connection, is true that in some countries, one of them being Canada, the law has been interpreted as meaning that a woman and her foetus in utero are to be treated legally as one person, not two - as one patient for a doctor, nurse, or midwife [26]. This position, however, is not shared by the majority of the UN member countries and - more important - has never been articulated or accepted at an international level. On the contrary, as shown above, several international instruments clearly go in the opposite direction. Even in the extreme case of a pregnancy resulting from rape, it seems difficult to defend the existence of a human right for the woman to terminate the pregnancy. Indeed from a juridical viewpoint it seems difficult to defend how, in addition to the just and harsh punishment of the aggressor, it would be proper to mandate suppression of the product of conception. Finally, in the event of II trimester abortions carried out to protect the health of the pregnant woman, rather than a right to suppress the foetus, the focus should be on the need to exercise every precaution to ensure its survival.

Secondly, in most countries where IA has been legalised, the law has also recognised the right to conscientious objection for health personnel who might be required to perform the pregnancy termination. Apart from a discussion on the nature of this right which some scholars consider to be a fundamental one to be specifically recognised - it is the very existence of this option that puts the RA in question. The contention that physicians and paramedical personnel can be excluded from the obligation to perform or assist in performing IA, even without giving specific reasons, can only depend on the respect that all legislators should have for legitimate personal views of individuals, especially those following the age-old tradition inaugurated by Hippocrates (to cultivate and actively promote a particular model of medical profession). It does also depend on a significant malaise of professional categories involved vis-à-vis the performance of an abortion.

As, mentioned, many proponents of a RA have evoked the existence of "reproductive rights" as specified in the definition of "sexual and reproductive health". However these rights cannot be utilised in building a "case" for a "right to abortion" in a legal sense, since it remains unclear what "good" (as meant in the definition of human rights) may arise from IA, since no one has ever presented suppression of prenatal life as a good in itself. The "functional necessity" to have an abortion, even to restore the physical (or even psychological) health of the pregnant woman, is not enough to turn it into a "good" and in many, if not all, cultures IA is not perceived as a "good" by the woman, the couple, or the family, or even by civil society.

In conclusion, in spite of recent efforts to present the issue "abortion is a human right" as having a simple and straightforward affirmative answer, the fact of the matter is that - as pointed out in the San José Declaration - IA to the present day has not been included in the list of rights protected by binding legal documents, whether national or international. Voluntary pregnancy termination remains a practice that - depending on the country - has been decriminalised, or formally allowed even on demand, but has never received the attribute of an "individual human right". This is even more so, when we consider that the only way to reconcile the legal status of abortion as a permissible practice, with the equally important and repeatedly stressed imperative to use any possible means to reduce the number of unwanted pregnancies and therefore of abortions $[6,17]$, is to consider IA as an intrinsically negative act, to be accepted with qualification.

From a practical point of view, a number of additional issues remain when attempting to define a "right to abortion". The first and most important is the temporal extent of a hypothetical right. The 
resolution approved by OCSE's Parliamentary Assembly [17] speaks of "within reasonable gestational limits" and this goes a long way to show that even the proponents do not know what to propose. Almost all legislations on IA make a distinction between I and II trimester abortion. The first can be obtained on demand in many countries; the second is available on demand only in some $5 \%$ of all countries of the globe [27]. It is not at all clear whether the proponents of the RA, wish to maintain such a distinction and, if so, on what biological, juridical or philosophical grounds. If the right to obtain an IA should not be made dependant on whether gestation has gone beyond the end of the third month, then all women in the world should have the right to terminate a pregnancy on demand until viability is reached. This, however, means that the infamous practice of female foeticide [28] should be accepted without restrictions as part of the RA, leading the way to accepting the proposal recently made by two utilitarian philosophers to legalise infanticide, renaming it "after birth abortion" [29].

\section{Abortion from an Anthropological Point of View}

We believe that, at least in the Western World, the bioethical and legal debate surrounding IA stems from a radical tension on its true meaning [30]. A reflection on human procreation leads to the conclusion that an ancient, but still present dichotomy exists between what could be named biologic and naturalistic ("in the flesh") generation, resulting from a fecund sexual act; and a symbolic one ("in the word"), stepping-in only when, having become aware of the pregnancy, the woman voluntarily accepts her offspring. In this scenario, unless the second step occurs, the new being cannot enter the process leading to its identification as a social and not merely biologic individual.

In reality no compelling reason can induce a pregnant woman to accept or negate her "in the word" acceptance. Indeed, if such reasons existed, acceptance would no longer be free. This means that, in our view, no real difference exists between a new being "in the flesh" only and one confirmed "in the word". Exercising a decisional power over a new early life is not objectionable per se; however, if, on the one hand, this option has been made easier from a legal and technical standpoint, on the other, IA continues to be the focal point where two contradictory constraints meet and need to be reconciled. Choosing one or the other cannot be negated, while at the same time it cannot be fully legitimised [31]. We believe that this is the main reason why often IA is the object of a denial: if possible it is avoided; if "necessary", it is not publicly manifested and is not considered to be represented [30,32].

Performing an abortion definitely means exercising power; it also means assuming consequential responsibilities, since the act involves the suppression of a new life. The rights of the new being may well be considered subordinated to the rights of the woman, but it is difficult to imagine that throughout two trimesters of intrauterine life the embryo and then the foetus have no rights whatsoever. The concept of autonomy, so often used in this context [33], calls into the debate the concepts of personhood and human dignity: to affirm an "absolute right to abortion" it is therefore preliminarily necessary to radically deny any subjectivity to the new developing human being. Such an attempt has been challenged both logically and juridically: In Italy, the 1975 decision of the Constitutional Court [22] that served as a basis for decriminalising abortion, made clear that the reality was one of conflicting interests between subjects with different degrees of juridical personality. A similar approach has been taken by the German Constitutional Court [34] and has been elaborated by Habermas [35].

We agree that gestation is a process involving the concept of privacy that strictly pertains to the intimate life of a woman and, as such, cannot be forcefully constricted in any given direction without breaking a fundamental human right [30]. At the same time, procreation also implies an intimate relationship between a woman and a man and, more generally, individual reproduction represents the conditio sine qua non for social reproduction and for the continuity of our species.

It is because reproduction is still such an important part of the lives of most people that abortion is still viewed as a negative act. Some believe that the increasing availability and utilisation of medical abortion will contribute to a "normalisation" of the psychological and social issues by creating a different perspective for IA [36]. We doubt that this assumption is founded, since medical abortion involves a mini labour and, if anything may exacerbate doubt in those women considering it a sheer, but unwelcome, necessity [30]. At the same time, this type of reasoning confuses the "mean" with "end", in the hope that the evolution of the first will end-up modifying the second.

In conclusion, at the heart of the problem of abortion there is an unavoidable tension between the exercise of a power that cannot be totally justified, namely to request an abortion, and the still widespread consensus of the existence of a right to life (i.e. the confirmation "in the word") of all generated "in the flesh". This tension can be managed in many ways, as the ancient history of abortion gave us ample testimony; today, the prevailing consensus is that management should follow a "parental project" [30], but this constitutes a practical arrangement, not an "unrestricted human right". Human logic, legal theory and practical experience do not permit to affirm the existence of a right, which would coincide with the proclamation of a universal denial to those born "in the flesh" to receive confirmation "in the word".

\section{References}

1. Center for reproductive Rights (2013) The World's Abortion Laws map.

2. The San José Articles (2011) Abortion and the Unborn Child in International Law.

3. United Nations (1948) The Universal Declaration of Human Rights.

4. United Nations General Assembly (1959) Declaration of the Rights of the Child [Resolution 1386(XIV) of 20 November 1959].

5. United Nations General Assembly (1979) Convention on the Elimination of All Forms of Discrimination against Women [Resolution 34/180 of 18 December 1979].

6. UNFPA (United Nations Population Fund) (1995) Report of the International Conference on Population and Development - ICPD - Programme of Action. UNFPA A/CONF 171/13/Rev. 1.

7. United Nations Entity for Gender equality and the Empowerment of Women (UN Women) (1995) Fourth World Conference on Women. Action for Equality, Development and Peace (4-15 September 1995 - Beijing, China).

8. IShankar Singh J (1998) Creating a New Consensus on Population. London: Earthscan.

9. Sauerbrey E (US Ambassador to the UN). Declaration at the Fiftieth Session of the UN Commission on the Status of Women.

10. The Charter of the Fundamental Rights of the European Union (2010) Official Journal of the European Union, C 83/38930.3.2010).

11. European Union (2007) Treaty of Lisbon. Official Journal of the European Union C 306, 17.12.2007

12. Council of Europe (2008) The European Convention on Human Rights [Signed in Rome on, 4.XI.1950].

13. United States Supreme Court (1973) Roe vs. Wade. Decision 410 U.S. 113, 93 S. Ct. 705,35 L. Ed. $2 d 147$.

14. Tribe L (1973) The Supreme Court, 1972 Term - Foreword: Toward a Model of Roles in the Due Process of Life and Law, 87 Harvard Law Review 1, 7. 
15. Lazarus E (2002) The lingering Problems with Roe v. Wade and why the Recent Senate hearings on Michael McConnell's Nomination Only Underline Them, Find Law Legal Commentary, October 3.

16. Ely JH (1973) The Wages of Crying Wolf: A Comment on Roe v. Wade, Yale Law Journal 82: 920-949.

17. Council of Europe, Parliamentary Assembly (2008) Access to safe and legal abortion in Europe.

18. Bundesverfassungsgericht (German Constitutional Court) (1993). Judgment of May 28, 1993, BverfG, 88 BVerfGE 203-205 (DBR).

19. Rieger HJ (1993) Opinion of the German Federal Court on abortion, Deutsche Medizinische Wochenschrift 118:1127-30.

20. Gobierno de España (Government of Spain) (2010) Ley Orgánica 2/2010, de 3 de marzo, de salud sexual y reproductiva y de la interrupción voluntaria del embarazo (Organic law 2/2010, of 3 march, on sexual and reproductive health and on voluntary interruption of gestation). BOE-A-2010-3514

21. Repubblica Italiana (1978) Legge 22 maggio 1978, n. 194. Norme per la tutela sociale della maternità e sull'interruzione volontaria della gravidanza [Law of 22 May 1978, No. 194. Norms for the social protection of motherhood and for voluntary pregnancy termination]. Gazzetta Ufficiale no. 140, 22May 1978.

22. Corte Costituzionale (Italian Constitutional Court) (1975).

23. United Nations (2013) Human Rights.

24. Locke J. (1690) An Essay concerning the True Original, Extent, and End of Civil Government.

25. Bobbio N (1991) The Age of Rights, [1989; trad. A. Cameron], Polity, Cambridge UK.

26. The Society of Obstetricians and Gynaecologists of Canada (2012) Position
Statement on Motion M-312: Creation of a committee to discuss when human life begins.

27. Boland R. (2010) Second trimester abortion laws globally: actuality, trends and recommendations. Reprod HIth Matters 18: 67-89.

28. Sen A (1992) Missing women. Social inequality outweighs women's survival advantage in Asia and North-Africa. Brit Med J 304: 587-8.

29. Giubilini A, Minerva F (2012) After-birth abortion: why should the baby live? J Med Ethics 39: 261-263.

30. Boltanski L (2004) La condition foetale: Une sociologie de l'engendrement et de l'avortement [The fœtal condition: A gender and abortion sociology]. Gallimard, Paris.

31. Sandel MJ (2010) Justice: What's the Right Thing to do? Farrar, Straus and Giroux, New York.

32. D'Agostino F (2011) Aborto [Abortion] Bioetica e biopolitica: Ventuno voci fondamentali [Bioethics and Biopolitics: twenty-one fundamental issues] Giappichelli, Torino.

33. Dworkin R. (1994) Life's Dominion: An Argument About Abortion, Euthanasia and Individual Freedom. Vintage Editor, London.

34. The German Constitutional Court issued a ruling on May 28, 1993 (2 BvF 2/90, 2 BvF 4 and 5/92) to the effect that Paragraphs 218, Sections 1 and 219 of the pregnancy and family protection law (SFHG) of July 27, 1992, were unconstitutional.

35. Habermas J (2001) The Future of human Nature, Polity, Cambridge UK.

36. Bartolommei S (2008) Aborto: da 'deprecabile rimedio' a 'diritto civile della persona' [Abortion: from a 'condemnable remedy' to a 'person's civil right'] Bioetica 16: 462-70. 